\title{
The environmental factors affecting service satisfaction of community hospital
}

\author{
Tanut Waroonkun* \\ Building Technology Innovation and Management Center, Faculty of Architecture, \\ Chiang Mai University, Thailand \\ *tanut.w@cmu.ac.th
}

Received : 27 September 2017 Final Version Received: 13 February 2018

Community Hospital in Thailand is a small-size hospital and available at a 'local level. Established by the Thai government some thirty years ago, the hospitals now find their facilities are unable to cope with increasing numbers of patients due to population growth. The re-furbishment of the old buildings in the hospital was needed in order to respond to these changes. Past extensions to the hospitals have focused more on form and function of the built environment rather than "needs" of the users (patients/family). However, research has shown that there are multiple aspects that affect a positive user experience in a hospital. This is especially true for the environmental aspect, which helps patients feel more comfortable and relaxed both mentally and physically when using community hospital services. There is a need therefore, to establish which of the environmental factors are important to a positive user experience. In this study, factors related to the built environment and their effect on the user experience were broadly categorized as Ambient Features, Architectural Features, Interior Design Features and Outdoor Environment Features. Each of these consisted of further sub-categories of importance to the user. Twenty users of Sara Phi Community Hospital were interviewed to determine what was important to them as users of the hospital. This hospital was chosen for convenience. The AHP model was used to establish a rank order of those factors considered important in determining user satisfaction. In-depth interview and questionnaires provided data for final analysis. The study found that Ambient Features had the highest impact score (0.343) followed by Architectural Features (0.260), Interior Design Features (0.224) and Outdoor Environment Features (0.173). The secondary factors that make up the main factors were ranked according to their weighted contribution to overall satisfaction. The paper discusses these factors with support for the respective rank. Suggestions are made for future development of this strategy of investigation

Keywords: Built Environment, User Experience, Community Hospital, Satisfaction.

\section{INTRODUCTION}

Thai Community Hospitals were established by the Thai Public Health system some thirty years ago as a public utility. A Community Hospital was established in each sub- district of each province. The Community hospital is a small-size hospital, however, it covers all areas in the country and it is closer to residents. The total number of community hospitals in the country is 770 , with a bed count ranging from 10 to 60 depending on the geographical area (Ministry of Public Health, 2015). Community hospitals differ from General Hospitals in as much as the latter are much larger structures, with bed counts in the hundreds, and are located in the provincial capitals or in Bangkok. However, since the time the hospitals were established the population has been steadily increasing thus placing extra demand on the community hospitals. From the time the community hospital initiative was developed the population of Thailand has increased by some sixteen million (Department of Provinical Administration, 2017) Consequently, Community Hospitals were forced to expand, as the original structures were not able to accommodate the demand for extra space and facilities. During the expansion period, because of necessity and economic considerations form and function were given 
priority in construction of extra facilities, little consideration was given to the ease and comfort of the hospital users with regard to the built environment.

Pongyen and Waroonkun (2015) suggested that the majority of community hospitals lack positive physical environmental conditions. This lack generally led to many problems which directly affected users' satisfaction with the hospital experience. Hospital users reported negative feelings such as worry, anxiety and uncomfortableness. These negative feelings may have an effect on medical treatment and slow down patients' recovery (Pongyen and Waroonkun 2015). Many different causes contributed to this problem. For example, the size of the building extension and the utilization of space affected the building' $s$ layout and aesthetics. Also, the original internal air conditioning systems were found to be inadequate for the extra space.
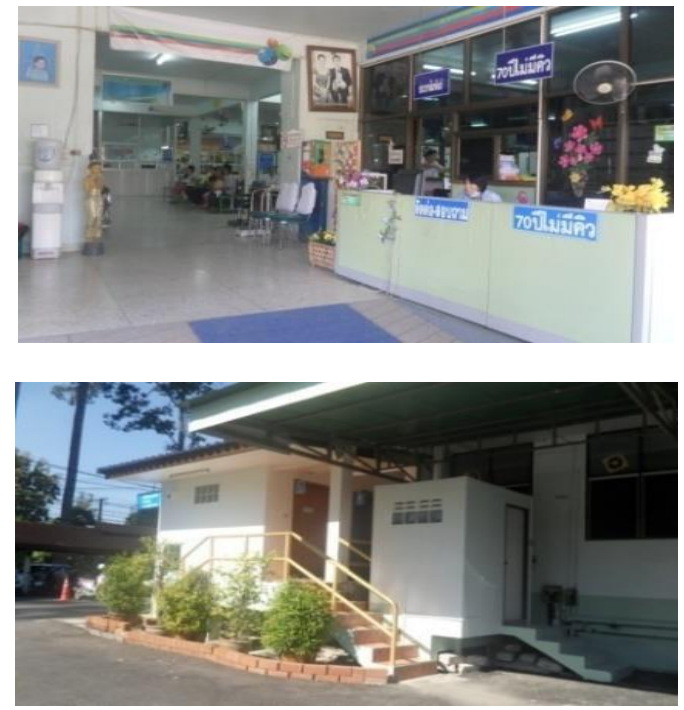

Renovation of Sara Phi Community Hospital improved usability but ruined the aesthetics of the building

Following from the Pongyen and Warookun (2015), this paper recognizes the need for extension and renovation of hospital facilities but argues that there should be more emphasis on the satisfaction of the user. "Hospitals can be distressing and even traumatic places to visit, so anything that can be done to improve the experience is surely welcome" (Callaghan, D., $2010 . p 18$ ) Clearly then, improvement of the hospital environment should increase the quality of treatment and patients' health. Patients who are more relaxed and familiar with the environment will experience less negative emotion. This in turn provides a ' healing environment' that will enhance recovery through a positive experience. Hamilton (2011) opines that, "An anxious or ill patient can be negatively affected by subtle stimuli, so the typical medical waiting room can be an obstacle to effective treatment. Ulrich et al. (1991) argues that any stimulus that impacts in a positive sense would not outweigh a stimulus that has a negative impact in terms of user satisfaction. Environments that encourage the building' s users in a positive sense and do not cause negative feelings can be called the healing environment.

This present study focuses on the physical environment of the hospital as a factor influencing the user experience in an outpatient hospital setting. The concern is for the 'built environment'. It does not consider the quality of the service encounter (e.g. staff attitude, interaction with others), issues of cost (e.g. financial costs, perceived value of service(, nor process (e.g. service flow, difficulties at various stages within the process).

An analysis of the factors having a significant effect on the satisfaction of the hospital user will provide valuable information for further redevelopment of the hospital environment. Evidence shows that patients (and families) that have a positive experience in all aspects of the hospital service will be less stressed which in turn will facilitate the healing process. A significant feature of the hospital in this regard is its built environment. The perceptions of those using the hospital service will have a definitive influence on their feelings and behaviour. Hence it is important to consider these issues when designing future developments. As Harris et al. (2002) report, “...design communities have been moving hospitals away from the sterile institutional designs of the past toward friendlier, more intimate designs for patient areas and grander, more welcoming designs for public areas" (p.1281)

The objective of this study is to determine those specific factors that influence user satisfaction in a Thai Community Hospital out-patient setting. An analysis of these factors will provide input for professionals tasked with designing future hospitals or involved in the upgrade of current building.

\section{LITERATURE REVIEW}

Tracey et al. (2007) have studied several factors that influenced patients' perception of service quality in the hospital treatment process. They 
divided service quality perceptions into four dimensions: interpersonal quality, technical quality, environment quality, and administrative quality. The primary dimension 'environment quality' was further reduced to secondary dimensions: 'atmosphere' and 'tangibles'. Atmosphere was described as those elements of the environment that were "below conscious level of awareness" (p.135). As an example they report an interview response relating to 'hospital smells'. 'Tangibles' the authors suggest, relate to physical elements of the environment: design, function, layout, signs, and colour.

This current work adopts the results of a study by Harris et al. (2002) in which they classified the 'healing environment' into three categories: Ambient Features, Architectural Features and Interior Design Features. Although Harris et al. (2002) include a further primary factor of influence: 'Maintenance/Housekeeping', this item was not considered in the present study as the focus here is on the physical environment as constructed.

Community hospitals are small and integrated with their 'outdoor environment' (e.g. garden surrounds, parking facilities, outside communal area - where people can wait if inside the hospital wait if inside the hospital wait area is particularly crowded). Thus, in addition to the primary categories suggested by Harris et al. (2002), this study includes Outdoor Environment Features as a possible factor influencing hospital visitors' user experience (see also Pongyen \& Waroonkun 2015). Each of the categories and the contributing research support are outlined below:

- Ambient Features: lighting, temperature, noise level, air quality and smells were chosen as secondary factors in this feature as they affect both positive and negative feelings. This is more so when the user has no control over these factors.

- Architectural Features means factors that relate to building design or the architectural elements of buildings. The secondary factors in the table below are related to the user experience. Secondary factors here include: the entrance, windows, layout, floor material, and toilet elements. All these factors can affect the efficiency and facilitation of services Table 2 shows the secondary factors that indicated meaning of Architectural Features

- Interior Design Features relate to those elements that are subtly experienced by the hospital user. They include greenery, television, colour, furniture, and signage. These factors facilitate usage and enhance the environment for patients. Interior design involves the use of features that can enhance a sense of ease. Design elements can divert attention from the waiting or feelings of anxiety.

- Outdoor Environment Features relate to those activities and elements that take place outside the building, but influence the user's comfort. Outdoor Environmental Features include: view \& surroundings, building extensions, rest areas, parking, and additional services. Such factors will affect users the minute they arrive at the hospital. A good outdoor environment will enhance a positive image for the entire hospital and set a precursor mood for the user.

Table 1. Secondary factors included in the environment main factor 'Ambient Features'

\begin{tabular}{|c|c|c|}
\hline $\begin{array}{l}\text { Secondary } \\
\text { Factors }\end{array}$ & Definition & References \\
\hline Lighting & $\begin{array}{l}\text { Natural and Artificial light help to improve patients' health by } \\
\text { reducing sadness, excitement and agitation }\end{array}$ & $\begin{array}{l}\text { Higgins et al, 2007; Benedetti et al, } \\
2001\end{array}$ \\
\hline Temperature & $\begin{array}{l}\text { An appropriate temperature has a positive effect on patient health. } \\
\text { Feelings of too hot or too cold will result in the perception of an } \\
\text { uncomfortable environment }\end{array}$ & $\begin{array}{l}\text { Schwartz et al, 2004; Hellgren et al, } \\
2011\end{array}$ \\
\hline Noise level & $\begin{array}{l}\text { Hospital noise; outdoor activity, announcements, and surrounding } \\
\text { events, if louder than an acceptable level, patients will feel } \\
\text { uncomfortable. }\end{array}$ & $\begin{array}{l}\text { Konkani, A. and Oakley, B. 2012; } \\
\text { Christensen, M. } 2005\end{array}$ \\
\hline Air Quality & $\begin{array}{l}\text { Good ventilation, controlled- air quality, and air-flow throughout } \\
\text { the building can promote a healthy environment. }\end{array}$ & $\begin{array}{l}\text { Everett, W. D. and Kipp H. 1991; } \\
\text { Atkinson, J. and World Health } \\
\text { Organization. 2009. }\end{array}$ \\
\hline Odors & $\begin{array}{l}\text { Smells can have a therapeutic effect, change your mood for the } \\
\text { better and make you satisfied. The opposite is also true. }\end{array}$ & $\begin{array}{l}\text { Barcan, R. 2014; Guilemany et al, } \\
2011\end{array}$ \\
\hline
\end{tabular}


Table 2. Secondary factors included in the main environment factor 'Architectural Features'

\begin{tabular}{|c|c|c|}
\hline Secondary Factors & Definition & References \\
\hline Entrance & $\begin{array}{l}\text { The entrance is a significant first factor for hospital users. The entrance } \\
\text { should be easily recognizable, clear, and not confusing. }\end{array}$ & $\begin{array}{l}\text { Hans et al 2006; Moore, } \\
2012\end{array}$ \\
\hline Window & $\begin{array}{l}\text { The location, type, and size of windows affects the ambience of hospital } \\
\text { environment. Windows provides sunlight, air-flow, and an outside view. } \\
\text { This encourages healing. }\end{array}$ & $\begin{array}{l}\text { Atkinson, J. and World } \\
\text { Health Organization. } \\
\text { 2009. }\end{array}$ \\
\hline Layout & $\begin{array}{l}\text { Layout must correspond with treatment process, reduce wait time, prevent } \\
\text { stress, and enhance understanding of the treatment process }\end{array}$ & $\begin{array}{l}\text { Yi and Seo, 2012; } \\
\text { Arnolds and Stefan, } \\
2013\end{array}$ \\
\hline Floor Material & $\begin{array}{l}\text { Floor material should be slip-proof and sound absorbing. This will provide } \\
\text { for the safety and comfort of hospital users. }\end{array}$ & Harris and Laura 2013. \\
\hline Toilet Elements & $\begin{array}{l}\text { Toilet should be designed for safety, convenience and ease of use. The } \\
\text { location of the toilets will have a significant impact on overall user } \\
\text { experience. }\end{array}$ & $\begin{array}{l}\text { Logan K. 2012; Hignett } \\
\text { S. and Evans D. } 2006\end{array}$ \\
\hline
\end{tabular}

Table 3. Secondary factors included in the main environment factor 'Interior Design Features'

\begin{tabular}{|c|c|c|}
\hline Secondary Factors & Definition & References \\
\hline Greenery & $\begin{array}{l}\text { Ornamental or natural plants of good quality strategically placed in the } \\
\text { building }\end{array}$ & $\begin{array}{l}\text { Vincent et al 2010; } \\
\text { Marcus and Marni } 1999\end{array}$ \\
\hline Television & $\begin{array}{l}\text { Providing appropriate TV programmes for patients while they are waiting } \\
\text { can provide a distraction. However, content and volume are important } \\
\text { issues. }\end{array}$ & $\begin{array}{l}\text { Hamilton 2011; Catsi et } \\
\text { al } 1998\end{array}$ \\
\hline Colour & $\begin{array}{l}\text { Colour affects human perception and response to the environments; certain } \\
\text { colours are associated with calmness and positive mood experience. }\end{array}$ & $\begin{array}{l}\text { Dalke et al 2005; } \\
\text { Nicholson and Joshua } \\
2007\end{array}$ \\
\hline Furniture & $\begin{array}{l}\text { Furniture should be appropriate for use by patients; can be flexible } \\
\text { depending on the type of the activity, personal, feel secure, and be easily } \\
\text { moved. }\end{array}$ & $\begin{array}{l}\text { Jonsson et al 2014; } \\
\text { Burton } 2001\end{array}$ \\
\hline Signage & Signs must be correctly designed and have a clear message. & $\begin{array}{l}\text { Cooper and Berger 2009; } \\
\text { Cooper } 1998\end{array}$ \\
\hline
\end{tabular}

Table 4. Secondary factors included in the main environment factor "Outdoor Environment Features"

\begin{tabular}{|c|c|c|}
\hline $\begin{array}{l}\text { Secondary } \\
\text { Factors }\end{array}$ & Definition & References \\
\hline Surroundings & $\begin{array}{l}\text { The natural environments around the building can produce an initial mood } \\
\text { response in the hospital user. The hospital 'image' can lead to feelings of } \\
\text { confidence and certainty in the visitor }\end{array}$ & $\begin{array}{l}\text { Marcus and Marni } \\
\text { 1999; Williams et al } \\
2008\end{array}$ \\
\hline $\begin{array}{l}\text { Building } \\
\text { extensions }\end{array}$ & $\begin{array}{l}\text { The building extensions can be seen to increase utility space, responding to } \\
\text { treatment and enhance service quality. The quality of the extension work can } \\
\text { effect overall perceptions of the hospital. }\end{array}$ & $\begin{array}{l}\text { Pongyen and } \\
\text { Waroonkun } 2015\end{array}$ \\
\hline Rest Areas & $\begin{array}{l}\text { Provision of tables and chairs, and reading area in different points outside the } \\
\text { building }\end{array}$ & $\begin{array}{l}\text { Burton } \\
\text { Pongyen } \\
\text { Waroonkun }\end{array}$ \\
\hline Parking & Parking space is convenient for patients, the disabled, and others. & $\begin{array}{l}\text { Davy et al 2008; } \\
\text { Rubin } 2011\end{array}$ \\
\hline $\begin{array}{l}\text { Additional } \\
\text { Services }\end{array}$ & Other amenities such as cafes, convenience stores, and wifi for users. & $\begin{array}{l}\text { Pongyen and } \\
\text { Waroonkun } 2015\end{array}$ \\
\hline
\end{tabular}

Based on previous research on environmental factors within the hospital, a hierarchical structure for these features was developed (See Fig.1). Factors influencing satisfaction levels of people using the hospital building can be categorized under four key factors and twenty secondary factors.

These factors are used as the basis for further analysis of the hospital in terms of user experience in the survey questionnaire. 


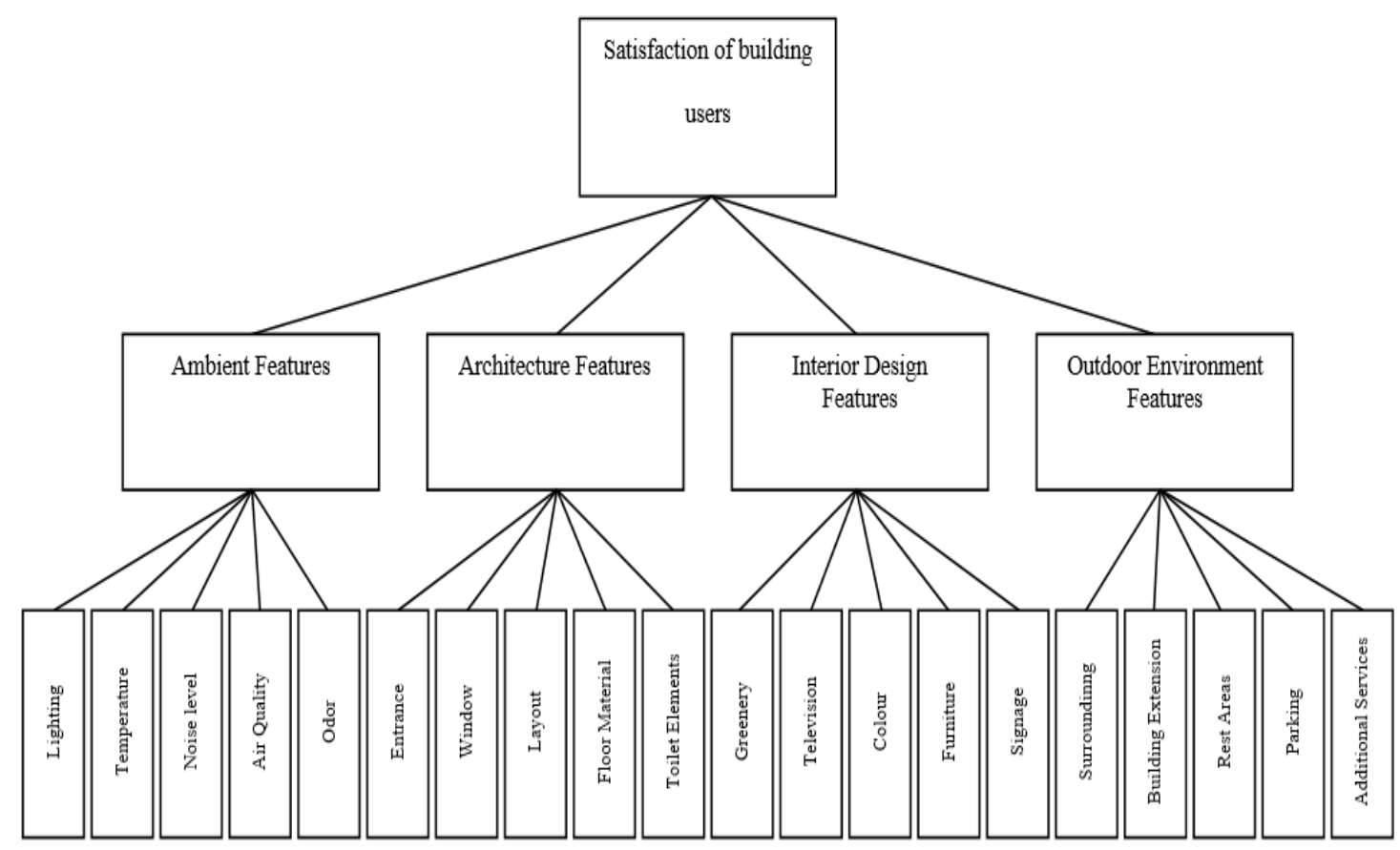

Figure 1. The hierarchy structure of environmental factors in a hospital building

\section{METHOD}

In order to determine the significance of the factors contributing to user satisfaction, the analysis utilized the Aanalytic Hierarchy Process (AHP) method. The AHP method is used as a tool for logical decision making. It has been widely used in general research and is acknowledged to be reliable (Saaty, 1980). The AHP uses pair-wise comparisons, hierarchical structures, and 9-point ratio scaling. The hierarchical structure (Figure 1) used for this analysis was developed through a review of prior research on factors affecting user satisfaction in a hospital setting.

Twenty visitors to a Community Hospital in Northern Thailand were interviewed for this study. Each respondent completed a questionnaire and an in-depth interview with a member of the research team. As required by AHP analysis this study used a small group of people who had real experiences as users of the hospital setting at Sara Phi Community Hospital The questionnaire consisted of a pair-wise comparison of the four main factors that contributed to the overall feeling of satisfaction with the hospital building. In addition, the respondents rated the relative importance of each of the secondary factors to the main factor in the hierarchy. In total respondents were required to make forty-six (46) judgements. In each case a member of the research team sat in proximity to the respondent to answer queries about the survey and to later conduct an interview to discuss the repondent's choices and reasoning, if the respondent agreed to do so .

\section{RESULTS}

The matrix calculation of the environmental factors in community hospitals and significant ratios are shown in Table 5. The sample consisted of 20 people who were using the hospital on the interview day. For a sample of twenty respondents, the $\mathrm{CR}$ values should be less than 0.1 or $10 \%$ for the comparison of five secondary factors and less than 0.09 or $9 \%$ for the comparison of four main factors (Saaty,1980).

The Consistency Ratio (CR) and Consistency Index (CI) of each of the environmental factors were as follows;

CI Main factor $=0.041$, CR Main factor $=0.038$

CI Ambient features $=0.043$

CR Ambient features $=0.038$

CI Architectural features $=0.050$

CR Architectural features $=0.045$

CI Interior Design features $=0.056$

CR Interior Design features $=0.050$

CI Outdoor Environment features $=0.043$

CR Outdoor Environment features $=0.03$ 
Table 5. Overall Weights and Ranks of the Factors Effecting User Satisfaction

\begin{tabular}{|c|c|c|c|c|c|c|}
\hline Purpose & $\begin{array}{l}\text { Level } 1 \text { (Main } \\
\text { Factors) }\end{array}$ & Eigenvector & $\begin{array}{c}\text { Level } 2 \\
\text { (Secondary } \\
\text { Factors) }\end{array}$ & Eigenvector & Weight & Ranking \\
\hline \multirow{20}{*}{ Satisfaction } & \multirow{5}{*}{$\begin{array}{l}\text { Ambient } \\
\text { features }\end{array}$} & \multirow{5}{*}{0.343} & Lighting & 0.179 & 0.061 & 4 \\
\hline & & & Temperature & 0.333 & 0.114 & 1 \\
\hline & & & Noise Level & 0.145 & 0.050 & 10 \\
\hline & & & Air Quality & 0.187 & 0.064 & 3 \\
\hline & & & Odours & 0.156 & 0.054 & 8 \\
\hline & \multirow{5}{*}{$\begin{array}{l}\text { Architectural } \\
\text { features }\end{array}$} & \multirow{5}{*}{0.260} & Entrance & 0.184 & 0.048 & 11 \\
\hline & & & Window & 0.139 & 0.036 & 14 \\
\hline & & & Layout & 0.207 & 0.054 & 9 \\
\hline & & & $\begin{array}{c}\text { Floor } \\
\text { Material }\end{array}$ & 0.144 & 0.037 & 12 \\
\hline & & & $\begin{array}{c}\text { Toilet } \\
\text { Elements }\end{array}$ & 0.326 & 0.085 & 2 \\
\hline & \multirow{5}{*}{$\begin{array}{l}\text { Interior Design } \\
\text { features }\end{array}$} & \multirow{5}{*}{0.224} & Greenery & 0.280 & 0.036 & 13 \\
\hline & & & Television & 0.093 & 0.021 & 20 \\
\hline & & & Colour & 0.121 & 0.027 & 18 \\
\hline & & & Furniture & 0.259 & 0.058 & 6 \\
\hline & & & Signage & 0.247 & 0.055 & 7 \\
\hline & \multirow{5}{*}{$\begin{array}{l}\text { Outdoor } \\
\text { Environment } \\
\text { features }\end{array}$} & \multirow{5}{*}{0.173} & Surroundings & 0.164 & 0.028 & 17 \\
\hline & & & $\begin{array}{c}\text { Building } \\
\text { Extensions }\end{array}$ & 0.134 & 0.023 & 19 \\
\hline & & & Rest Areas & 0.178 & 0.031 & 15 \\
\hline & & & Parking & 0.341 & 0.059 & 5 \\
\hline & & & $\begin{array}{l}\text { Additional } \\
\text { Services }\end{array}$ & 0.182 & 0.031 & 16 \\
\hline
\end{tabular}

\section{DISCUSSION}

In terms of the main factors affecting user perception, the results show that "Ambient Features" (0.343) was the factor that had the most impact on users' satisfaction. Each of the secondary factors for this feature related to the users' senses and concomitant feelings. Interview data suggest that the over-riding feelings were negative. For instance, the high temperature coupled with the poor ventilation system inside the building caused discomfort, which affected the satisfaction level of the users. "Architectural Features" (0.260) were the next level of importance for users. These features relate particularly to the building design and layout. For the users this equates to ease of use and a general sense of "control" over their situation. Closely related to Architectural Features are "Interior Design Features" (0.224). Interior Design represents that way the internal built structure is equipped to enhance comfort, ease of use and overall functionality.
The significance of the secondary features 'furniture' and 'signage' is relevant here. Of least significance to the users in this study was "Outdoor Environment Features" (0.173). This is understandable as most of the time and activities the user is involved with at the hospital means they are waiting 'inside' the hospital. Of note, however, is the relatively high importance given to the secondary factor "parking".

A deeper analysis of the main factors in terms of the secondary factors in terms of their ranking (weight) highlights some interesting contributions to the user's overall sense of satisfaction (see table 5).

The most highly ranked for of all the secondary factors, was 'Temperature' (0.114). This result in combination with the third ranked factor 'Air Quality' (0.064): which relates to the ventilation system in the building, is not surprising. On the day the data was collected, Northern Thailand was experiencing some of the hottest weather for 
the period. On the day in question the temperature was in the high thirties (Celcius) for most of the day and evening. Interview data indicates that people felt hot and uncomfortable because the air conditioning was inadequate and there were insufficient fans. The second most important factor was 'Toilet Elements' (0.085). The feedback on this feature related to the location, cleanliness, and interiors of the toilets. Users felt that there were inadequate number of toilets, that maybe there should be toilets outside the building, but most important toilets should be kept clean and have a pleasant interior. Comment was made about the needs for wheelchair access and toilets appropriate for the elderly. It is worth mentioning here that the factor 'Odours' (0.054) ranked eighth on the list and related to the 'hospital smell' and exhaust fumes from outside the hospital. However, smells coming from the toilets were mentioned here in many of the responses but summing up the attitude (and lower ranking) was the comment 'you can just sit somewhere away from the toilets".

The fourth factor of importance was Lighting (0.061). The general feeling was that lighting was inadequate in most areas (dim). Many of the interview comments spoke of insufficient bright lamps (need for LED lights), and complained that many of the installed lights were not working. Other commented on the lack of natural light. (natural light' is problematic as the windows are tinted to reduce the effect of sunlight adding to internal temperature, and windows need to be closed to ensure efficient running of air conditioning)

On ranking, Furniture (0.058) was considered sixth in importance. Generally, hospital visits require lengthy waiting time. Functional, sturdy, and comfortable furniture was considered important. The main concern for respondents was the lack of sufficient seating. Next in rank $\left(7^{\text {th }}\right)$ was Signage $(\mathbf{0 . 0 5 5})$. Adequate signage is critical to reduce confusion and uncertainty in users of a facility. Users at the hospital reported that the signage was inadequate and confusing. But the effect on overall feelings of satisfaction was mitigated by the fact that hospital staff were forthcoming in helping those who were 'lost or confused'.

Layout (0.054) relates to the organization of the interior structure so as to facilitate procedures and process. Generally users were happy with the layout, but argued that at busy times the waiting area is inadequate to cope with, and comfortably seat, large numbers. Specific mentions were given to difficulties navigating to the Delivery Room. This would account for the rank in ninth position. Noise Level (0.050), although an issue with user satisfaction was not ranked as very important $\left(10^{\text {th }}\right)$.Users felt the noise level was generally acceptable provided they could hear the nurse's call, and have a conversation with their accompanying persons. The main issue was noise from the outside (traffic) and, on busy occasions, crowd noise in the hospital made it difficult to hear the nurse call the name of patients. When the PA system was used the noise level was not a problem.

Architectural Factors contributed to the next levels of user experience. Entrance (0.048): clear and obvious access to the hospital building $\left(11^{\text {th }}\right)$. There was difficulty accessing the building if ambulances or cars dropping-off or picking-up patients were parked at the main entrance. Further, the location of wheelchairs at the entrance made it difficult for people to enter/exit. Floor material (0.037) was not a main concern. Floor material was generally considered safe but old and in need of repair $\left(12^{\text {th }}\right)$. Windows $(\mathbf{0 . 0 3 6})$ were considered adequate $\left(14^{\text {th }}\right)$ but note the problems related to 'Lighting' mentioned above. Among these ranks Greenery (0.036) was ranked at \#13. Items contributing to this factor included the use of decoration and greenery within the hospital building. Users considered these items pleasant but not critical to their overall satisfaction.

'Outdoor Environment Features' was considered the least important of the main factors effecting user experience. Looking at the ranking of the secondary factors involved in this feature all are at the lower end of the ranking: Rest Areas (0.031): outside seating [15 $\left.{ }^{\text {th }}\right]$; Special Services (0.031): coffee shop, playground $\left[\mathbf{1 6}^{\text {th }}\right]$; Surroundings (0.028): grounds and gardens, decoration [17 ${ }^{\text {th }}$; and Extensions (0.023); renovations and building work that may affect the functioning of hospital services $\left[19^{\text {th }}\right]$. The exception was Parking (.059) which ranked fifth overall. Parking is the first introduction to the hospital and can have a significant effect on setting the tone for the users' perceptions. There is limited on-site parking available at the hospital. Lack of immediate parking can lead to negative feelings, such as frustration, especially when delivering patients to the hospital. This may explain why Parking has a relatively high ranking of importance for hospital users.

The final considerations were Colour (0.027) and TV $(\mathbf{0 . 0 2 1})$ ranked $18^{\text {th }}$ and $20^{\text {th }}$ respectively. Users felt the pastel shades of the colours used in the hospital were appropriate. However, there was a strong emphasis on the need to re-paint. 
Finally, users did not see much importance in having a TV. This is not surprising as most users engage in conversation or interact with their mobile devices.

The current study was confined to one community hospital in a defined geographic area (Sara Phi). The results observed in this investigation may well represent the views of a group of the population that are not shared by those in a different region of the country (Thailand). It is worth noting that the local languages in Thai regions can differ identifiably. This would suggest that there may be a 'cultural' difference between patients at different hospitals that may have some influence on their choice of importance of the various factors.

\section{CONCLUSION}

The factors effecting user experience in a hospital outpatient setting were investigated. The results clearly show a rank order of factors as determined by the user's perception. These factors are ranked in terms of significance to the respondent. In conjunction with respondent interviews, the reason for the ranking can be established. High ranking factors are considered to have more importance to the user. The lowranking factors are still considered relevant but do not share the same critical importance as earlier ranking factors. For example, "Parking" was highly ranked and considered a critical factor in terms of satisfaction. "Colour" on the other hand, was not ranked highly but was still considered an issue. Perhaps ranking may be described in terms such as "essential" ranging to "nice to have but not essential"

Clearly, the users of the hospital have a definite perception of what is important to their satisfaction with their hospital visit when considering the built environment. The most important of these being is the 'ambient features'. The suggestion is made here that those charged with the future design/re-furbishment of community hospitals conduct similar studies to determine what is important to the user.

There are, however, several issues that should be considered before adopting this model in future and which should be areas of further research. Survey results may be influenced by transient aspects. In this study, temperature was the most influential factor on reported user experience. But data was collected on an exceptionally hot day. Where would temperature rank on, say, a pleasant day? More meaningful results should arise if the survey is conducted on several sessions over a specified time. This may show clusters of factors that tend to be highly ranked on all occasions.

Perusal of interviews conducted during the study indicated different sentiments expressed by patients/visitors versus staff. In future studies, there should be a separation of the respondents. Clearly, the needs of patients/visitors to an outpatient section may be quite different to those who work in the environment. Of course, more power to the outcome if there are factors common to both groups. In a related argument, Tracey et al. (2007) draw attention to the " impact of analytical context markers such as frequency of patronage and the number of service encounters" (p.136) as having an influence on survey results. Staff at the hospital will possibly present a different profile of factors to that of the patients by virtue of the fact that staff use the buliding on a more regular basis.

The result of the current study should promote more thorough research in this area. Ultimately, the rank order of factors effecting user satisfaction can be, and should be, an integral input to effective design for construction or renovation of community hospital outpatient settings. Such research can help improve the design of the building in a way that is ' comforting' to the patients/ family (users) Comfort and lack of frustration with surrounds can only but help the ultimate goal of the hospital: patient satisfaction and subsequent recovery.

\section{REFERENCE}

Arnolds, I.V. and Stefan, N. (2013), Multi-Period Layout Planning for Hospital Wards, Socio-Economic

Sciences, $47 \quad$ (3):

Planning doi:10.1016/j.seps.2013.02.001.

Atkinson, J. and World Health Organization. (2009), Natural Ventilation for Infection Control in Health-Care Settings, Geneva: World Health Organization. http://www.ncbi.nlm.nih.gov/books/NBK1 43284/

Barcan, R. (2014), Aromatherapy and the Mixed Blessing of Feminization, The Senses and Society, 9 (1): 33-54. doi:10.2752/174589314X1383411276100.

Benedetti, F. Colombo, C. Barbini, B. Campori, E. and Smeraldi, E. (2001), Morning Sunlight Reduces Length of Hospitalization in Bipolar Depression, Journal of Affective Disorders, 62 (3): 221-223.

Bodin, L. and Epstein, E. (2000), Who's on First - with probability 0.4, Computer and Operations Research, 27(3): 205-215 
Burton, R. 2001, FURNITURE \& FURNISHINGS - Backing a Revolution in Furniture Design: - Richard Burton Calls for a Rethink in Hospital Furniture, Hospital Development 32 (4): 37

Catsi, G.N. Guirguis, N.O. Rissel, C. and Balafas, A. (2007), The Use of a Closed-Circuit Hospital Television Channel to Promote Health: The Reach and Appeal of RPA tv to Patients and Visitors, Australian Health Review 31 (4): 527-530.

Christensen, M. (2005), Noise Levels in a General Surgical Ward: A Descriptive Study, Journal of Clinical Nursing 14 (2): 156-164. doi:10.1111/j.1365-2702.2004.01040.

Cooper, R. (1998), Successful Signage: Take a Look at How These Hospitals Solved Their Wayfinding Challenges, HFMMAGAZINE, November 2014: 27-30

Cooper, R. and Berger, C.M. (2009), What's New in Wayfinding? Recent Developments in Hospital Signage, Health Facilities Management 22 (4): 23-30

Dalke, H. Jenny, L. Elga, N. Nilgun, C. Guillaume, S. Sarah, H. and Laura, S. (2006), Colour and Lighting in Hospital Design, Optics \& Laser Technology 38 (4-6)

Davy, C. Chris, L. Sheila, K. and Rick, W. (2009), Organisational Challenges When Enabling Ease of Access for the Elderly Around a Large Acute Hospital Campus, International Journal of EvidenceBased Healthcare 7 (4): 296-300. doi:10.1111/j.1744-1609.2009.00146.x.

Department of Provincial Administration, (2017),http://stat.dopa.go.th/stat/statnew/up stat_age.php

Devlin, A.S., (2015), Transforming the doctor's office: Principles from evidence-based design, Routledge

Everett, W.D. and Kipp H. (1991), Epidemiologic Observations of Operating Room Infections Resulting from Variations in Ventilation and Temperature, American Journal of Infection Control 19 (6): 277-282.

Guilemany, J.M. Mariño-Sánchez, F.S. Angrill, J. Alobid, I. Centellas, S. Pujols, L. Berenguer, J. Bernal-Sprekelsen, M. Picado, C. and Mullol, J. (2011), The Importance of Smell in Patients with Bronchiectasis." Respiratory Medicine 105 (1): 44-49. doi:10.1016/j.rmed.2010.10.019.

Hans, N. Markus, H. Julia, W. Sophie, S. Christina, L. (2006), The New Hospital. 2006, Singapore: Page One Pub
Hamilton, M. (2011), Healing can begin in your waiting room, Medical Economics.http://medicaleconomics.moder nmedicine.com/medicaleconomics/news/m odernmedicine/modern-medicine-feature articles/healing-can-begin-yourwaitin?page=full Accessed 26 July, 2017

Hamilton, M.M. (2011), Healing Can Begin in Your Waiting Room: Be Mindful of How Plants, Television, Music, and Artwork Affect the Patient Experience, MEDICAL ECONOMICS - ORADELL THEN MONTVALE NJ- 88 (9): 70-81.

Harris, P.B. Glen, M. Chet, R. and Linnea, C. (2002), A Place to Heal: Environmental Sources of Satisfaction among Hospital Patients $^{1}$, Journal of Applied Social Psychology $32 \quad$ (6): 1276-1299. doi:10.1111/j.1559-1816.2002.tb01436.

Harris, D.D. and Laura, A.D. (2013), The Role of Flooring As a Design Element Affecting Patient and Healthcare Worker Safety, Health Environments Research \& Design Journal (HERD) (Vendome Group LLC) 6 (3).

Hellgren, U.M. Markku, H. Rauno, H. and Kari, R. (2011), Perceived Indoor Air Quality, Air-Related Symptoms and Ventilation in Finnish Hospitals, International Journal of Occupational Medicine and Environmental Health $24 \quad$ (1): 48-56. doi:10.2478/s13382-011-0011-5.

Hignett, S. and Evans, D. (2006), Spatial Requirements in Hospital Shower and Toilet Rooms, Nursing Standard (Royal College of Nursing (Great Britain) : 1987) 21 (3): 43-48.

Higgins, P.A. Chris, W. Amy, R.L. Su-Er, G. and James, R. (2007), Light Measurement in the Hospital: A Comparison of Two Methods, Research in Nursing \& Health 30 (1): 120-128. doi:10.1002/nur.20167.

Jonsson, O. Britt, O. Anders, W. and Elisabeth, D.H. (2014), Furniture in Swedish Nursing Homes: A Design Perspective on Perceived Meanings Within the Physical Environment, Journal of Interior Design 39 (2): 17-35. doi:10.1111/joid.12028.

Konkani, A. and Oakley, B. (2012), Noise in Hospital Intensive Care Units-A Critical Review of a Critical Topic, Journal of Critical Care 27 (5): 522.e1-9. doi:10.1016/j.jcrc.2011.09.003.

Logan, K. (2012), Toilet Privacy in Hospital, Nursing Times 108 (5): 12- 13.

Marcus, C.C. and Marni, B. (1999), Healing Gardens : Therapeutic Benefits and Design Recommendations, Wiley series in healthcare and senior living design; New York:

Wiley. 
http://catdir.loc.gov/catdir/toc/onix06/9804 2154.htm

Moore, A. (2012), Estates Management: Case Studies. Dramatic Entrance, The Health Service Journal 122 (6300): 10-11.

Nicholson, M. and Joshua, M. (2007), Orientation with Colour, Practice Development in Health Care 6 (4): 242-244. doi:10.1002/pdh.233.

Pongyen, N. Waroonkun, T. (2015), Guideline design for improving outpatient building of a community hospital in order to increase satisfaction, Journal of Environmental Design 2.

Rubin, C.H. (2011), Park Place a Combination of Technology and People Prove to Be the Best Medicine for Securing Hospital Parking Garages, Security: Solutions for Enterprise Security Leaders 48 (5).

Saaty, T.L. (1980), The Analytic Hierarchy Process, McGraw-Hill, New York.

Schwartz, J. Samet, J.M and Patz, J.A. (2004), Hospital Admissions for Heart Disease: The Effects of Temperature and Humidity, Epidemiology (Cambridge, Mass.) 15 (6): 755-761.

Tracey, S.D, Jillian C.S. and Lester W.J. (2007), A Hierarchical Model of Health Service
Quality : Scale Development and Investigation of an Integrated Model, Journal of Service Research 10 (2): 123-142. doi:10.1177/1094670507309594.

Ulrich, R.S. Robert, F. Simons, B.D. Losito, E.F. Mark, A.M. and Michael, Z. (1991), Stress Recovery during Exposure to Natural and Urban Environments, Journal of Environmental Psychology 11 (3): 201-230. doi:10.1016/S0272-4944(05)80184-7.

Vincent, E.D. Battisto, L.G. and McCubbin, J. (2010), The Effects of Nature Images on Pain in a Simulated Hospital Patient Room, HERD: Health Environments Research \& Design Journal 3 (3): 42-55. doi:10.1177/193758671000300306.

Williams, A.M. Dawson, S. and Kristjanson, L.J. (2008), Exploring the Relationship between Personal Control and the Hospital Environment, Journal of Clinical Nursing $17 \quad$ (12): 1601-1609. doi:10.1111/j.1365-2702.2007.02188.x.

Yi, L. and Seo, H.B. (2012), The Effect of Hospital Unit Layout on Nurse Walking Behavior, HERD 6 (1): 66-82. 